\title{
Spectrin-based skeleton as an actor in cell signaling
}

\author{
B. Machnicka $\cdot$ R. Grochowalska $\cdot$ D. M. Bogusławska $\cdot$ \\ A. F. Sikorski $\cdot$ M. C. Lecomte
}

Received: 23 May 2011/Revised: 8 August 2011/Accepted: 10 August 2011/Published online: 30 August 2011

(C) The Author(s) 2011. This article is published with open access at Springerlink.com

\begin{abstract}
This review focuses on the recent advances in functions of spectrins in non-erythroid cells. We discuss new data concerning the commonly known role of the spectrinbased skeleton in control of membrane organization, stability and shape, and tethering protein mosaics to the cellular motors and to all major filament systems. Particular effort has been undertaken to highlight recent advances linking spectrin to cell signaling phenomena and its participation in signal transduction pathways in many cell types.
\end{abstract}

Keywords Spectrin · Cell signaling ·

Spectrin-based skeleton $\cdot$ Membrane skeleton

Spectrins: several genes and numerous isoforms widely distributed in all metazoan cells

Spectrins are large flexible molecules that exist mainly as heterotetramers made of various $\alpha$ and $\beta$ subunit isoforms.

B. Machnicka - R. Grochowalska - D. M. Bogusławska Faculty of Biological Sciences, University of Zielona Góra, Zielona Góra, Poland

A. F. Sikorski ( $\square)$

Laboratory of Cytobiochemistry, Biotechnology Faculty,

University of Wroclaw, Wroclaw, Poland

e-mail: afsbc@ibmb.uni.wroc.pl

M. C. Lecomte

Inserm, UMR-S 665, Paris 75015, France

M. C. Lecomte

Universite Paris Diderot, Paris 7, Paris 75013, France

M. C. Lecomte

Institut National de la Transfusion Sanguine, Paris 75015, France
The $\alpha$ and $\beta$ subunits are assembled side to side in an antiparallel fashion to form rod-like $\alpha \beta$ dimers that in turn self-associate head to head to form tetramers. Tetramer formation involves the $\mathrm{N}$-terminus of each $\alpha$ subunit with the $\mathrm{C}$-terminus of each $\beta$ subunit. The $\beta$-spectrin chains can also exist as homopolymeric complexes in skeletal muscle [1] and possibly in the Golgi apparatus [2, 3]. Each extremity of tetramers binds actin microfilaments via $\beta$-spectrin, allowing spectrin to form cross-links between actin filaments, thus generating an extended network.

Spectrins are expressed in all metazoan cells arising from numerous genes. Therefore, in mammals, the different spectrin isoforms originate by extensive mRNA splicing from seven genes. Two genes, SPTA1 and SPTAN1, encode $\alpha \mathrm{I}-$ and $\alpha \mathrm{II}-$ spectrin subunits, respectively. In contrast to SPTA1, the SPTANl gene codes for several $\alpha$ II-spectrin isoforms present in all non-erythroid cells, resulting from three alternative splicing processes [4-6]. Five genes code for $\beta$-spectrins: four "conventional" $\beta$ genes, $S P T B$, $S P T B N 1, S P T B N 2, S P T B N 4$, encoding the $\beta \mathrm{I}-\beta \mathrm{IV}$ spectrins, respectively, and one gene, $S P T B N 5$, encoding one large $\beta \mathrm{V}$-spectrin ( $\beta$-Heavy) [7, 8]. The expression of the diverse isoforms is regulated in a complex tissue- and developmental stage time-specific manner (Tables 1,2).

Invertebrates have a smaller repertoire of spectrin genes. The Caenorhabditis elegans and Drosophila melanogaster genomes include a single gene coding for an $\alpha$-spectrin closed to the mammalian $\alpha \mathrm{II}-$ spectrin [spc-1 and I(3)dre3, respectively] $[9,10]$ and two genes coding for $\beta$-spectrin; one codes for a $\beta_{\mathrm{G}}$ protein resembling the mammalian $\beta \mathrm{II}-$ spectrin referred to as "conventional $\beta$-spectrin" (Unc-70/ bgs-1 and $\beta$-Spc) [11], and the other (sma 1 in C. elegans and karst in $D$. melanogaster) encodes $\beta \mathrm{H}$-spectrin ( $\beta$-Heavy similar to mammalian $\beta \mathrm{V}$ ) $[12,13]$. Greater sequence conservation is observed between spectrins from 
Table 1 Spectrin genes and their expression in mammalian tissue

\begin{tabular}{|c|c|c|c|c|}
\hline Subunit & Gene & Chromosome & Tissue expression & Ref. \\
\hline \multicolumn{5}{|c|}{ Homo sapiens } \\
\hline$\alpha \mathrm{I}$ & SPTA1 & $1 q 21-q 23$ & Isoform $\alpha \mathrm{I} \Sigma 1 \mathrm{RBC}$ and isoform $\left(\alpha \mathrm{I} \Sigma^{*}\right)$ in brain & {$[7,8]$} \\
\hline$\alpha \mathrm{II}$ & SPTAN1 & $9 q 33-q 34$ & Several isoforms present in all non-erythroid cells & {$[4,5,132]$} \\
\hline$\beta \mathrm{I}$ & $S P T B$ & $14 q 22-q 23.2$ & $\begin{array}{c}\beta \mathrm{I} \Sigma 1 \text { erythrocytes, } \beta \mathrm{I} \Sigma 2 \text { isoforms in brain and muscle, } \\
\beta \mathrm{I} \text {-spectrin was also detected in lymphocytes }\end{array}$ & {$[8,18,50,100]$} \\
\hline$\beta \mathrm{II}$ & SPTBN1 & $2 q 21$ & All nucleated cells & {$[8,50,100]$} \\
\hline$\beta \mathrm{III}$ & $S P T B N 2$ & $11 \mathrm{q} 13$ & $\begin{array}{l}\text { Golgi and vesicular membrane skeletons, plasma membrane in } \\
\text { neurons and epithelial cells }\end{array}$ & {$[49,113]$} \\
\hline$\beta \mathrm{IV}$ & SPTBN4 & $19 q 13.13$ & $\begin{array}{l}\text { Neurons (axon, initial segment, nodes of Ranvier) and } \\
\text { pancreatic islets, nucleus }\end{array}$ & {$[6,130]$} \\
\hline$\beta \mathrm{V}$ & SPTBN5 & $15 \mathrm{q} 21$ & $\begin{array}{l}\text { Low level in many tissues, outer segments of photoreceptor } \\
\text { rods and cones, basolateral membrane of gastric epithelial } \\
\text { cells and outer hair cell (OHC) }\end{array}$ & {$[59,60]$} \\
\hline
\end{tabular}

Table 2 Examples of spectrin functions in cellular processes and signaling

\begin{tabular}{|c|c|c|}
\hline Spectrin isoforms & Function in cellular processes/signaling & Ref. \\
\hline$\alpha \mathrm{I}$ & Supports RBC shape and maintains cell membrane integrity and its mechanical properties & {$[14,51,52,131]$} \\
\hline \multirow[t]{6}{*}{$\alpha \mathrm{II}$} & Engaged in maintaining cell architecture, morphology, and plasma membrane stability & {$[53-55]$} \\
\hline & Engaged in regulation of neurite outgrowth stimulated by NCAM & {$[64]$} \\
\hline & Participates in the organization of specialized membranes-TRPC4 channels & {$[65,66]$} \\
\hline & Engaged in cell adhesion and spreading, regulation of actin dynamics & {$[84,91]$} \\
\hline & Modifies cell cycle by altering cell adhesion & [84] \\
\hline & $\begin{array}{l}\text { Engaged in DNA interstrand cross-links repair, connected to maintaining chromosomal } \\
\text { stability }\end{array}$ & {$[85-87,90]$} \\
\hline \multirow[t]{3}{*}{$\beta \mathrm{I}$} & Supports RBC shape and maintains cell membrane integrity and its mechanical properties & {$[51,52]$} \\
\hline & Contributes to the formation of TCR complexes in lymphocytes & {$[99,100,109]$} \\
\hline & Involved in early cellular apoptotic events & {$[110,111]$} \\
\hline \multirow[t]{3}{*}{$\beta \mathrm{II}$} & $\begin{array}{l}\text { Engaged in cell morphology and mechanical properties, compaction and accumulation of } \\
\text { E-cadherin in the epithelial cell-cell contact }\end{array}$ & {$[56,57]$} \\
\hline & Delivery of proteins and phospholipids to the membrane & {$[3,30,31,47]$} \\
\hline & Cell cycle regulation by involvement in $\mathrm{TGF} \beta$ signaling & {$[75,76,80-82]$} \\
\hline \multirow[t]{2}{*}{$\beta$ III } & Participates in the organization of the glutamate transporter EAAT4 in Purkinje cells & {$[70,71]$} \\
\hline & Facilitates membrane protein transport via the secretory and endocytic pathways & [112-114] \\
\hline \multirow[t]{2}{*}{$\beta \mathrm{IV}$} & $\begin{array}{l}\text { Regulates localisation of voltage-gated channels at the axon initial segment and node of } \\
\text { Ranvier, synchronizes action potentials, provides multifunctional regulatory platform for } \\
\text { sodium channels, plays an important role in the structure and stability of excitable } \\
\text { membranes in heart and brain }\end{array}$ & {$[72,73,133]$} \\
\hline & Involved in targeting of critical structural and regulatory proteins & [134] \\
\hline \multirow[t]{2}{*}{$\beta \mathrm{V}$} & Engaged in cell flexibility & [59] \\
\hline & Engaged in OHCs' electromotility & {$[60]$} \\
\hline
\end{tabular}

Drosophila and non-erythroid spectrin than between the erythroid and non-erythroid forms within the mammalian organism. Sequence analyses suggest that the erythroid spectrin genes arose during vertebrate evolution, and some of the sequence changes may correspond to neo-functionalization of the erythroid spectrin genes [14-16].
Despite the diversity of the genes, each spectrin subunit is made up of a succession of triple helical motifs called spectrin repeats (roughly 106 amino acid residues long), flanked by non-homologous $\mathrm{N}$ - and C-terminal sequences $[7,17,18] . \alpha$-Spectrins contain 20 spectrin repeats $(\alpha 1-\alpha 20), \beta$-spectrins are made of 17 spectrin repeats ( $\beta 1-\beta 17)$, while the heavy $\beta \mathrm{V}$-spectrins contain 30 repeats. 


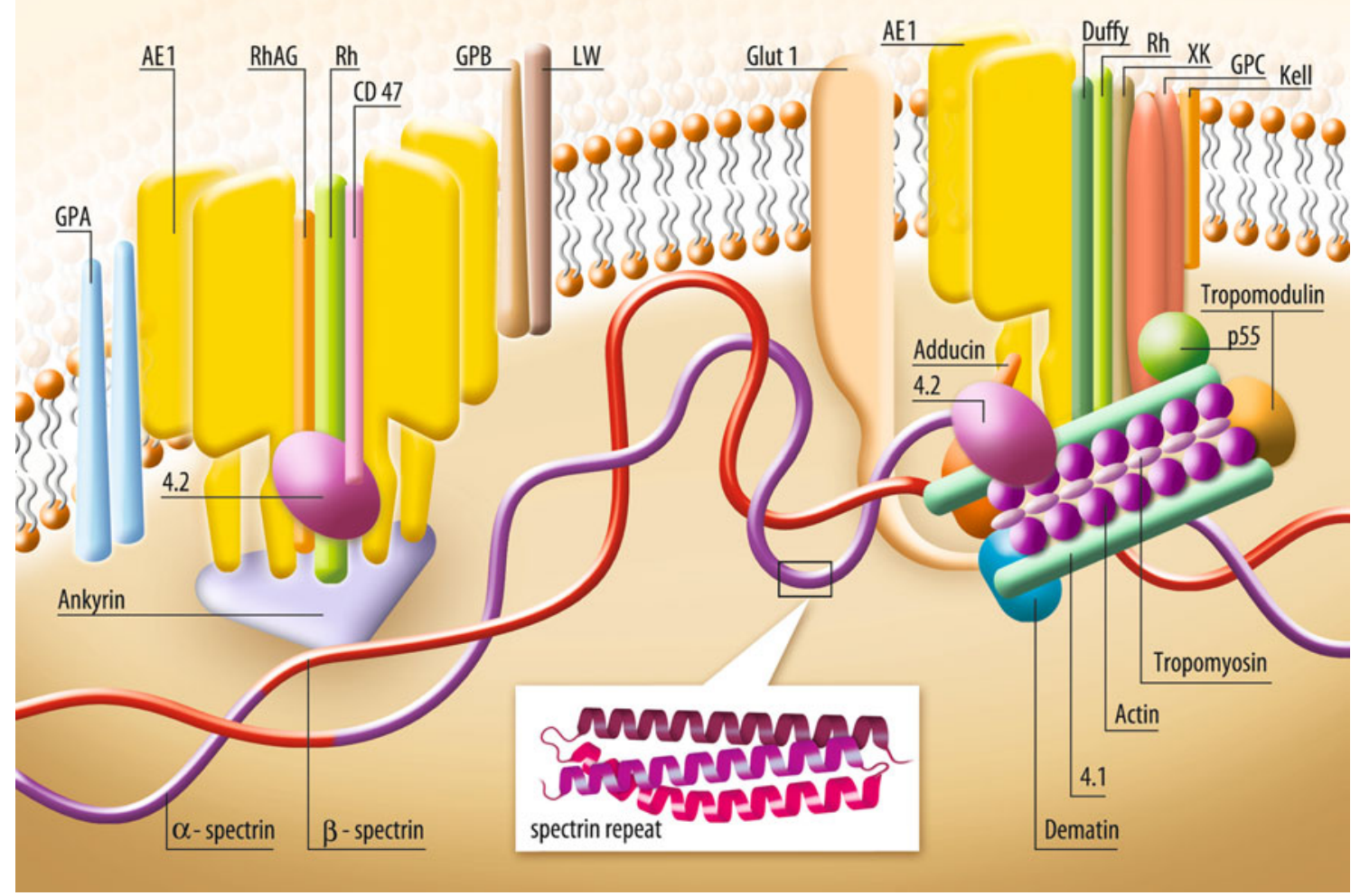

Fig. 1 A model of the human red cell membrane. The spectrin-actin interaction is modulated by accessory proteins such as protein 4.1, together with dematin, adducin, tropomyosin and tropomodulin. Their functions are to stabilize the actin-spectrin complex, to maintain actin filament length (adducin acts as a capping protein), and to bind the spectrin-based network to the transmembrane proteins (the glycophorin $\mathrm{C}$, the anion exchanger AE1) via adapter proteins (protein p55 and protein 4.2). Another major binding site to membrane is mediated via ankyrin, which binds to $\beta$-spectrin and the anion exchanger AE1. The $\mathrm{Rh} / \mathrm{RhAG}$-ankyrin complex can be also a link between the red

The structure of the repeat unit (folded in a triple $\alpha$-helical coiled-coil structure) and their interconnection are thought to be closely associated with spectrin flexibility [19]. When stretched, spectrin tetramer filaments can reach $\sim 200 \mathrm{~nm}$ in length. Besides roles in the structure and the flexibility of spectrins, spectrin repeats can be considered as an interaction platform. Some spectrin repeats are involved in the formation of spectrin dimers and tetramers, such as the $\alpha 17-\alpha 20$ repeats with $\beta 1-\beta 4$ repeats, and the first helix of $\alpha$-spectrin with the last incomplete $\beta 17$ repeat of $\beta$-spectrin, respectively [20-22]. Moreover, they are also essential to the binding of the spectrin-based membrane skeleton to the membrane bilayer (Fig. 1). In erythrocytes, the $\beta 14-15$ repeat region is bound to the anion exchanger (AE1) via ankyrin [23]. Another major membrane bilayer binding site is the protein 4.1 complex, which includes actin, dematin, adducin, tropomyosin and tropomodulin. This complex binds the spectrin-based network to glycophorin $\mathrm{C}$ and the anion AE1 by adapter proteins p55 and 4.2 [24-27]. The cell membrane and the spectrin-based skeleton. Spectrins also interact directly with phospholipids such as phosphatidylserine and phosphatidylethanolamine, membrane components actively confined to the inner leaflet of the lipid bilayer. The aminophospholipid-binding sites in $\beta$-spectrin are localized in close proximity to the attachment sites for both ankyrin and 4.1, the proteins engaged in spectrin links to the membrane. $A E 1$ anion exchanger, $G P A$ glycophorin $\mathrm{A}, G P B$ glycophorin B, GPC glycophorin C, GLUT 1 glucose transporter 1, $R h$ rhesus factor, $R h A G$ Rh-associated glycoprotein

4.1 complex also stabilizes the actin-spectrin interaction and maintains actin filament length. Spectrins also interact directly with phospholipids such as phosphatidylserine and phosphatidylethanolamine, a component actively confined to the inner leaflet of the lipid bilayer [28-34]. All these interactions are crucial for maintaining membrane mechanical properties. Recent data revealed that $\alpha$-spectrin repeats can directly interact with membrane proteins such as the adhesion molecules Lu/BCAM (involving the $\alpha 4$ repeat) $[35,36]$. Furthermore, there are still unexplained relationships between proteins exported by the malaria parasite Plasmodium and $\alpha$-spectrin repeats (for a review, see [37].

Besides the spectrin repeats, spectrins contain additional sequences that can facilitate some protein-protein or protein-lipid interactions. $\alpha$-Spectrins contain an SH3 domain within the $\alpha 9$-spectrin repeat, which is well known to be engaged in cell signaling mainly by interacting with proline-rich stretches [38]. At the C-terminal end they also 
contain two EF-hand motifs related to calmodulin and involved in calcium binding [39-41]. $\alpha$ II-Spectrin differs from $\alpha \mathrm{I}$-spectrin by a 35 -residue insert in the $\alpha 10$ repeat, which bears a $\mathrm{Ca}^{2+}$-dependent binding site for calmodulin [42] and cleavage sites for both caspases (2 and 3) [43] and for $\mathrm{m}$ and $\mu$ calpains [44]. All $\beta$-spectrins contain an actinbinding domain in their $\mathrm{N}$-terminal region composed of a tandem of two $\mathrm{CH}$ (calponin homology) domains, which is present in many spectrin-related and unrelated skeletal proteins [45, 46]. The C-terminal region of the "long" isoforms of $\beta$-spectrins contains a $\mathrm{PH}$ (pleckstrin homology) domain responsible for phosphoinositide binding [47-49].

While mammalian erythrocytes contain only one type of spectrin tetramer made of $\alpha \mathrm{I}$ and $\beta \mathrm{I}$ subunits, located at the inner surface of the membrane, nucleated cells can contain several spectrin species. Numerous isoforms of $\alpha$ - and $\beta$-spectrins derived from different genes are located in diverse cellular compartments (membrane, Golgi apparatus, endoplasmic reticulum, vesicles and nucleus). Some isoforms have a specific expression according to cell type or to cell organelle with very specific functions. The inactivation of the genes encoding canonical spectrin in $D$. melanogaster or in C. elegans indicated that these proteins are essential for the survival and normal development of these organisms (for review see [50]).

\section{Spectrins are multifunctional proteins involved in regulation of cell morphology and mechanical properties}

In erythrocytes the spectrin-based network supports cell shape, and maintains cell membrane integrity and its mechanical properties (for reviews, see [51, 52]). The role of spectrin in determining the physical properties of red blood cell membrane was clearly documented in hereditary hemolytic anemia associated with mutations in both $\alpha$ I- and $\beta$ I-spectrins. Indeed molecular defects in erythroid spectrins are associated with abnormal shape, increased membrane fragility and reduced erythrocyte deformability.

Similarly, in nucleated cells the spectrin-based skeleton is involved in cell architecture, morphology, and plasma membrane stability [53-55]. In epithelial cells, knockdown of either $\beta$ II-spectrin or ankyrin $\mathrm{G}$ results in loss of the lateral membrane, expansion of the apical and basal membrane area, and conversion of cells from columnar to squamous morphology [56, 57]. Both proteins are required for compaction and accumulation of E-cadherin in the epithelial cell-cell contact, and the delivery of proteins and phospholipids to the lateral membrane [56]. Recent data suggest that in Drosophila, $\beta_{\mathrm{H}^{-}}$spectrin (homolog to mammal $\beta \mathrm{V}$-spectrin) at the apical membrane coordinates the interaction between cadherin-based zonula adherens, with the immunoglobulin cell adhesion molecule Roughest during eye morphogenesis [4, 58].

Spectrins also participate in cell flexibility outside the red blood cells. This property is conferred by mammalian $\beta \mathrm{V}$-spectrin and its homologs $\left(\beta_{\mathrm{H}}\right.$ spectrin in D. melanogaster and Sma-1 in $C$. elegans). These $\beta \mathrm{V}$ spectrin homologs have independently maintained an unusual 30-repeat length throughout evolution, which helps to cross-link membrane actin and confers extensive flexibility in cells $[19,59]$. In the outer hair cells (OHC) $\alpha$ II-, $\beta$ II- and $\beta \mathrm{V}$-spectrins together with $\mathrm{F}$-actin form the cortical network involved in the sound-induced electromotility. The main function of this spectrin-actin network is to provide flexible properties required for lateral wall contractionelongation cycles. While $\beta$ II-spectrin is restricted to the cuticular plate, a dense apical network of actin filaments, $\beta \mathrm{V}$-spectrin is concentrated at the cortical lattice and is directly involved in the OHCs' electromotility [60].

Both $\alpha$ - and $\beta$-spectrins are required during nervous system development. $\beta$-Spectrin interacts directly with the neural cell adhesion molecule NCAM, a synaptic adhesion molecule involved in mechanical stabilization of neuronal contacts [61, 62]. Genetic variations of NCAM are considered a risk factor in bipolar affective disease and schizophrenia [63]. In another way, $\alpha$ II-spectrin $(\alpha 12$ repeat) phosphorylation-dependent interaction with 14-3-3, a protein involved in neuronal migration and synaptic plasticity, acts as a switch between positive and negative regulation of neurite outgrowth stimulated by NCAM [64].

This short survey of published data presented in this paragraph suggests that various spectrins are strongly involved in supporting cell architecture and morphology in non-erythroid cells.

\section{Spectrins are a structural platform for stabilization and activation of membrane microdomains}

The spectrin-based skeleton participates in the organization of specialized membranes. When spectrin or its binding partner ankyrin is lost from or defective in cells, their interacting membrane partners do not accumulate at the appropriate site within the membrane (for review, see [65]). The surface expression and activation of the hTRPC4 channel (human Transient Receptor Potential Channel 4) is partially regulated by way of a direct interaction with spectrin. In $\alpha$ II-spectrin-depleted cells, the TRPC4 channels failed to undergo membrane insertion [66]. Mutations in $\beta$ III-spectrin are the cause of spinocerebellar ataxia type 5 (SCA5) and neurodegenerative disease [49, 67-69]. $\beta$ IIISpectrin defects are associated with mislocation of the glutamate transporter EAAT4 at the surface of the plasma 
membrane in Purkinje cells [70, 71]. $\beta$ IV-Spectrin knockout mice exhibit tremors and contraction of the hindlimbs. Loss of $\beta \mathrm{IV}$-spectrin observed in quivering mice with hearing loss is associated with mislocation of voltage-gated channels at the axon initial segment and node of Ranvier. Alterations in the location of sodium and potassium channels at myelinated nerves slow propagation and desynchronize action potentials [72, 73]. So, $\beta$ IV-spectrin acts as a multifunctional regulatory platform for sodium channels, and has important roles in the structure and stability of excitable membranes in heart and brain, targeting critical structural and regulatory proteins. In Drosophila, loss of $\beta$-spectrin led to the loss of $\mathrm{Na}^{+} \mathrm{K}^{+}$-ATPase from the basolateral domain of epithelial cells [74]. In an extreme case, loss of a variant of $\beta$ II-spectrin in mice led to death in utero [75].

As described above, the spectrin-based membrane skeleton controls the disposition of selected membrane channels, receptors, transporters and adhesion molecules. Defects in spectrins result in destabilization of the membrane structure, lead to serious neurodegenerative diseases and are involved in pathological processes.

\section{Spectrins, cell cycle and DNA repair}

Other studies suggest the participation of spectrin in cell cycle regulation. Spectrin might be involved in $\operatorname{TGF} \beta$ signaling. Proteomic studies revealed the presence of spectrin in a complex including TGF $\beta$-R1 (transforming growth factor $\beta$ receptor-1) [76]. The loss of $\beta$-spectrin results in defective $\operatorname{TGF} \beta$ signaling as manifested by mislocation of proteins that modulate the activity of TGF $\beta$ — smads 3 and 4 [75]. Spectrins are also components of the G-protein-coupled receptor (GPCR) complex [77] and the synaptic multiprotein complex [29, 78, 79]. These data indicate that spectrins are involved in the cell cycle by regulating the expression of membrane receptors. It is also noteworthy that in a mouse model, downregulation of expression of ELF, an isoform of $\beta \mathrm{II}-$ spectrin, confers susceptibility to tumorigenesis: $\beta \mathrm{II}-\mathrm{Sp}+/-$ mutant mice develop frequent tumors associated with deregulation of cell cycle control at the G1/S transition and defective TGF $\beta$ signaling [80-82]. Moreover, these $\beta \mathrm{II}-\mathrm{Sp}+/-$ mice are born with many phenotypic characteristics observed in Beckwith-Wiedemann syndrome (BWS), a hereditary stem cell cancer syndrome. These include dramatic visceromegaly, followed in later months by the development of multiple cancers, including carcinomas of the gastrointestinal tract, as well as renal and adrenal adenocarcinomas. Epigenetic silencing of $\beta$ II-spectrin expression in human BWS could be a potential causal factor in this stem cell disorder [83].
Furthermore, in $\alpha$ II-spectrin-depleted melanoma cells, increased expression of p21 (an inhibitor of cyclin-dependent kinase) was observed, which was associated with cell cycle arrest in the G1 phase. Spectrin depletion could secondarily modify the cell cycle by altering cell adhesion [84]. Although the detailed roles of spectrins in cell cycle regulation remain to be elucidated, spectrins should be considered as important elements in transduction pathways of extracellular signals controlling the cell cycle.

$\alpha$ II-Spectrin is present in nuclei of human cells and could play an important role in the repair of DNA interstrand cross-links. $\alpha$ II-Spectrin is deficient in cells from patients with Fanconi anemia (FA) [85]. It colocalizes with the cross-link repair protein XPF and FANCA, one of the Fanconi anemia proteins, in cross-link-induced nuclear foci [86, 87]. Another FA protein, FANCG, contains a motif that interacts directly with the SH3 domain of $\alpha$ II-spectrin. It plays a role in maintaining $\alpha$ II-spectrin stability in the cell [88]. $\alpha$ II-Spectrin could be particularly important in some of the initial steps of the cross-link repair process, which involves incision and unhooking of the cross-link via XPF/ERCC1 [89]. After cell damage, $\alpha$ II-spectrin binds to DNA at the sites of damage and acts as a scaffold, contributing to the recruitment of repair proteins. Moreover, $\alpha$ II-spectrin is involved in maintaining chromosomal stability. Depletion of $\alpha$ II-spectrin in normal human cells results in chromosomal instability, as evidenced by an increased number of interchromatid exchanges, fusions/ radials and breaks. It leads to decreased cell growth and survival [90]. These studies demonstrate the importance of $\alpha \mathrm{II}-$ spectrin in the repair of DNA interstrand cross-links.

\section{Spectrin contributes with actin to cell adhesion and spreading}

A newly proven role of $\alpha$-spectrin is its participation in cell adhesion and spreading via its SH3 domain. $\alpha$ II-Spectrin is present in a specialized type of calpain-induced $\beta 3$ integrin signaling complexes. The SH3 domain appears to transmit signals required for Rac activation and lamellipodia extension [91]. Cells overexpressing the SH3 domain adhered to the substratum, and their calpain-induced integrin signaling complexes were formed, but Rac activation, lamellipodia extension and cell spreading were inhibited. Spreading was restored by overexpressing constitutively active Rac. Other data supported the involvement of $\alpha$ II-spectrin in actin reorganization [84]. Spectrin loss by siRNA impaired cell adhesion and spreading. Spectrindepleted cells exhibited modifications of the actin cytoskeleton, such as loss of stress fibers, alterations of focal contacts and modified expression of some integrins. Spectrin via its $\mathrm{SH} 3$ domain interacts with two members of 
the Ena/VASP (enabled/vasodilator-stimulated phosphoprotein) family: VASP [92] and EVL (Ena/VASP-like) [93, 94]. Ena/VASP proteins are found in focal contacts, cellcell contacts and highly dynamic membrane regions such as lamellipodia. These proteins appear to regulate adhesion and to control actin dynamics. Proteins of the Ena/VASP family are essential for actin remodeling upon $\mathrm{T}$ cell activation, formation and extensions of lamellipodia. Ena/ VASP proteins bind the adapter protein ADAP (expressed in T cells and myeloid cells), which participates in LFA-1 integrin clustering. Spectrin also interacts with other proteins involved in actin dynamics, such as Abi1 $[95,96]$ and proteins of the WASP (Wiskott-Aldrich syndrome protein) family. The $\mathrm{T}$ cells from patients with Wiskott-Aldrich syndrome show characteristic cytoskeletal defects [97] and impaired function [98].

Thus, these recent data pointed out an unexpected role of $\alpha$ II-spectrin in transmission of signals leading to Rac activation, adhesion, lamellipodia extension, and cell spreading through several ligands and partners regulating actin dynamics.

\section{Control of activation of transmembrane proteins}

The other example of spectrin participation in cell signaling is its contribution to the formation of TCR ( $\mathrm{T}$ cell receptor) complexes in lymphocytes. It has been clearly demonstrated that the spectrin-based skeleton via its two major proteins, spectrin and ankyrin, directly binds CD45 in lymphocytes [99, 100]. CD45 plays a pivotal role in antigen-stimulated proliferation of $\mathrm{T}$ lymphocytes and in thymic development. The catalytic activity of CD45 is required for TCR signaling and regulation. Human mutations in the CD45-encoding gene are the cause of severe combined immunodeficiencies (SCID) [101-103]. CD45deficient mice are severely immune-deficient, with very few peripheral $\mathrm{T}$ lymphocytes, defective thymocyte development and failed receptor-mediated activation [104]. The direct binding of spectrin to CD45 stimulates the PTPase activity of CD45 and also facilitates the movement of CD45 and CD3 to the lymphocyte surface [100].

In lymphoid-derived cell lines, spectrin is distributed in the cytoplasm, but appears very often as large aggregates [105]. These spectrin-rich large aggregates in lymphocytes contain several proteins, such as hsp70, receptor for activated $\mathrm{C}$ kinase-1 (RAC-1) and $\operatorname{PKC} \theta\left(\mathrm{Ca}^{2+}\right.$-independent subfamily of serine/threonine specific protein kinase $\mathrm{C}$ ) [106, 107]. Activation of lymphocytes by phorbol 12-myristate 13-acetate (PMA), T-receptor cross-linking and mild hyperthermia resulted in the formation of cytoplasmic spectrin aggregates [108]. Recruitment of intracellular proteins to the plasma membrane is a well- known event required for the initiation of signal transduction; the participation of spectrin in this event may indicate its signaling function in lymphocytes. These facts imply that occurrence of aggregation of spectrin and PKC $\theta$ in chemically and physically stimulated lymphocytes and formation of a large signaling complex at the site of TCR clustering in immunological synapses may be related phenomena [109].

Spectrin aggregation may also be associated with early cellular apoptotic events preceding a loss of membrane aminophospholipid asymmetry [110]. Concomitant PKC $\theta$ rearrangement in lymphocytes implies its relationship to spectrin aggregation and its participation in regulating early steps of apoptosis [111]. The redistribution of spectrin and PKC $\theta$ into a polar aggregate has also been observed in Jurkat T and HL60 cell lines during early apoptosis-induced by cytostatics. These changes seem to be restricted to spectrin and not to concern other cytoskeletal proteins such as actin or vimentin. Although spectrins are potential caspase $-3,-7$ and -8 substrates, these proteases exhibited minor involvement in the early apoptotic rearrangement of spectrin/PKC $\theta$. Moreover, spectrin aggregation was shown to be at least partially dependent on $\operatorname{PKC} \theta$ activity.

Taken together, we may state that spectrin also plays an important role in various pathways of regulation of cellular processes and signaling in lymphocytes, such as TCR formation, activation and early steps of apoptosis.

\section{Spectrins interact with proteins involved in intracellular traffic}

The multifunctional spectrin-based skeleton participates in the complexes linking various structures or organelles to the motors involved in microtubule-directed transport, and in the facilitation of membrane protein transport via the secretory and endocytic pathways [112]. $\beta$ III-Spectrin is present in the Golgi and vesicle membranes [49], and binds to the dynactin subunit ARP1, suggesting a possible role in transport [113]. In patients exhibiting spinocerebellar ataxia type 5 (SCA5), a mutation found in the calponin homology domain $(\mathrm{CH})$ alters the interaction of $\beta$ III-spectrin with ARP1 and consequently affects the stabilization of membrane protein, or may cause alterations in EAAT4 transport by disrupting the binding to ARP1 and dynein motor complex. Cell culture studies reveal that the L253P mutant of $\beta$ III-spectrin, instead of being found at the cell membrane, appears trapped in the cytoplasm associated with the Golgi apparatus. Moreover, L253P $\beta$ III-spectrin prevents correct localization of wt $\beta$ III-spectrin and prevents EAAT4 from reaching the plasma membrane. These data provide evidence for a dominant-negative effect of an SCA5 mutation and show that trafficking of both $\beta$ III-spectrin and 
EAAT4 from the Golgi is disrupted through failure of the L253P mutation to interact with ARP1 [114].

\section{Spectrin functions can be regulated by posttranslational modifications}

Several pathways of spectrin posttranslational regulation have been correlated to apoptosis/necrosis [115] as well as to secretion/endocytosis, vertebrate lens development [116] and pathologies in the central nervous system $[117,118]$.

The regulatory pathways affecting spectrin include the action of calcium ions, calmodulin and $\mathrm{Ca}^{2+}$-activated proteolysis. Proteolysis of spectrin leads to destabilization of the membrane scaffold and membrane remodeling. This process is under the control of several proteases- $\mathrm{m}$ - and $\mu$-calpains $\left(\mathrm{Ca}^{2+}\right.$-activated proteases) and caspases 2, 3 and 7 (activated during apoptosis) - and is highly regulated by $\mathrm{Ca}^{2+} / \mathrm{cal}-$ modulin and tyrosine phosphorylation. $\alpha$ II-Spectrin cleavage is highly influenced by $\mathrm{Ca}^{2+}$ homeostasis and calmodulin, which therefore represent a potential regulatory pathway for the stability and plasticity of the spectrin-based skeleton [43, 44]. In fusion of placental trophoblast cells, caspases rather than calpains mediate remodeling of the spectrin skeleton [119]. As was found recently, during early apoptosis, caspase 8 releases an $\mathrm{N}$-terminal fragment containing ABD as well as a C-terminal fragment of $\beta$ II-spectrin. The proteolysis in the $\mathrm{N}$-terminal region depends on 4.1 protein (Kołodziejczyk, Dubielecka 2011 in preparation).

The other regulatory pathway important during membrane skeleton remodeling is spectrin phosphorylation. $\beta$-Spectrin phosphorylation was reported to be essential in destabilization of the erythrocyte membrane skeleton [120122], disassembly of the skeleton during mitosis [123] and the control of Golgi stability [124]. Likewise, $\alpha$ II-spectrin is an important subject of tyrosine phosphorylation. Tyrosine phosphorylation/dephosphorylation in the calpain cleavage site of $\alpha \mathrm{II}$-spectrin by kinases and phosphatases is a mechanism that regulates this spectrin subunit's sensitivity to cleavage $[44,125]$. Spectrin is a key point of signal convergence between tyrosine/phosphatase and $\mathrm{Ca}^{2+}$ mediated signal cascades. This kind of control may be particularly important in vesicle trafficking, endocytosis, neurite outgrowth and NMDA receptor activation [126]. However, a study on homozygous mice expressing a mutant $\alpha$ II-spectrin designed to resist calpain and caspase cleavage questions the functional importance of this process in vivo [127].

Moreover, $\beta \mathrm{IV}$-spectrin might be involved in a regulatory mechanism for $\mathrm{Na}+$ channels (Nav1.5), via direct phosphorylation by $\beta \mathrm{IV}$-spectrin targeted calcium/calmodulin-dependent kinase II [128]. These findings provide evidence for an unexpected yet commanding molecular platform involving spectrin that determines vertebrate membrane excitability.

\section{Concluding remarks}

The role of different spectrin subunits and domains has been studied and explained progressively. The first discovered role of $\alpha \mathrm{I} \beta \mathrm{I}$-spectrin was to define the cell shape and to maintain cell membrane integrity and stability in erythrocytes. Defects in these skeletal proteins in red cells lead to hereditary hemolytic anemia.

In nucleated cells the functions of spectrins still remain to be elucidated. The occurrence of a variety of spectrin isoforms in different cells indicates that its functions may vary among different cells as a result of their specializations. In most cells spectrins are known to be engaged in determination of the cell shape, in maintaining cell flexibility, cell-cell contact, cell polarity and proliferation.

Moreover, spectrins are engaged in the organization and function of membrane integral proteins, such as ion channels, receptors and adhesion molecules in specialized membrane domains. The $\beta$-spectrin mutations induce destabilization of the membrane structure and mislocation of membrane receptors and channels, often leading to serious diseases, such as spinocerebellar ataxia and neurodegenerative diseases. Recent data have revealed that $\alpha$ II-spectrin mutations are associated with West syndrome, an epileptic encephalopathy [129]. Defects in this ortholog in Drosophila melanogaster and Caenorhabditis elegans larvae are lethal. These facts corroborate the crucial role of this protein. In the last few years, more and more reports providing new data concerning the previously unrecognized role of $\alpha$-spectrins in signaling pathways have appeared. The SH3 domain of spectrin plays an essential role in Rac activation, initiation of actin network formation, adhesion, lamellipodia extension, cell spreading and DNA repair. The spectrins are also engaged in different pathways of cell transduction and signaling in lymphocytes, such as TCR formation, activation and early steps of apoptosis.

Open Access This article is distributed under the terms of the Creative Commons Attribution Noncommercial License which permits any noncommercial use, distribution, and reproduction in any medium, provided the original author(s) and source are credited.

\section{References}

1. Bloch RJ, Morrow JS (1989) An unusual beta-spectrin associated with clustered acetylcholine receptors. J Cell Biol 108:481-493

2. Beck KA, Buchanan JA, Malhotra V, Nelson WJ (1994) Golgi spectrin: identification of an erythroid beta-spectrin homolog associated with the Golgi complex. J Cell Biol 127:707-723 
3. Devarajan P, Stabach PR, Mann AS, Ardito T, Kashgarian M et al (1996) Identification of a small cytoplasmic ankyrin (AnkG119) in the kidney and muscle that binds beta I sigma spectrin and associates with the Golgi apparatus. J Cell Biol 133:819-830

4. Cianci CD, Zhang Z, Pradhan D, Morrow JS (1999) Brain and muscle express a unique alternative transcript of alphaII spectrin. Biochemistry 38:15721-15730

5. Moon RT, McMahon AP (1990) Generation of diversity in nonerythroid spectrins. Multiple polypeptides are predicted by sequence analysis of cDNAs encompassing the coding region of human nonerythroid alpha-spectrin. J Biol Chem 265:4427-4433

6. Berghs S, Aggujaro D, Dirkx R Jr, Maksimova E, Stabach P et al (2000) betaIV spectrin, a new spectrin localized at axon initial segments and nodes of ranvier in the central and peripheral nervous system. J Cell Biol 151:985-1002

7. Sahr KE, Laurila P, Kotula L, Scarpa AL, Coupal E et al (1990) The complete cDNA and polypeptide sequences of human erythroid alpha-spectrin. J Biol Chem 265:4434-4443

8. Winkelmann JC, Forget BG (1993) Erythroid and nonerythroid spectrins. Blood 81:3173-3185

9. Byers TJ, Dubreuil R, Branton D, Kiehart DP, Goldstein LS (1987) Drosophila spectrin. II. Conserved features of the alphasubunit are revealed by analysis of cDNA clones and fusion proteins. J Cell Biol 105:2103-2110

10. Dubreuil RR, Byers TJ, Sillman AL, Bar-Zvi D, Goldstein LS et al (1989) The complete sequence of Drosophila alpha-spectrin: conservation of structural domains between alpha-spectrins and alpha-actinin. J Cell Biol 109:2197-2205

11. Byers TJ, Brandin E, Lue RA, Winograd E, Branton D (1992) The complete sequence of Drosophila beta-spectrin reveals supra-motifs comprising eight 106-residue segments. Proc Natl Acad Sci U S A 89:6187-6191

12. McKeown C, Praitis V, Austin J (1998) sma-1 encodes a betaHspectrin homolog required for Caenorhabditis elegans morphogenesis. Development 125:2087-2098

13. Dubreuil RR, Grushko T (1998) Genetic studies of spectrin: new life for a ghost protein. Bioessays 20:875-878

14. Salomao M, An X, Guo X, Gratzer WB, Mohandas N et al (2006) Mammalian alpha I-spectrin is a neofunctionalized polypeptide adapted to small highly deformable erythrocytes. Proc Natl Acad Sci U S A 103:643-648

15. Baines AJ (2009) Evolution of spectrin function in cytoskeletal and membrane networks. Biochem Soc Trans 37:796-803

16. Baines AJ (2003) Comprehensive analysis of all triple helical repeats in beta-spectrins reveals patterns of selective evolutionary conservation. Cell Mol Biol Lett 8:195-214

17. Speicher DW, Ursitti JA (1994) Spectrin motif. Conformation of a mammoth protein. Curr Biol 4:154-157

18. Winkelmann JC, Chang JG, Tse WT, Scarpa AL, Marchesi VT et al (1990) Full-length sequence of the cDNA for human erythroid beta-spectrin. J Biol Chem 265:11827-11832

19. Grum VL, Li D, MacDonald RI, Mondragon A (1999) Structures of two repeats of spectrin suggest models of flexibility. Cell 98:523-535

20. Li D, Tang HY, Speicher DW (2008) A structural model of the erythrocyte spectrin heterodimer initiation site determined using homology modeling and chemical cross-linking. J Biol Chem 283:1553-1562

21. Speicher DW, Weglarz L, DeSilva TM (1992) Properties of human red cell spectrin heterodimer (side-to-side) assembly and identification of an essential nucleation site. J Biol Chem 267:14775-14782

22. Ursitti JA, Kotula L, DeSilva TM, Curtis PJ, Speicher DW (1996) Mapping the human erythrocyte beta-spectrin dimer initiation site using recombinant peptides and correlation of its phasing with the alpha-actinin dimer site. J Biol Chem 271:6636-6644

23. Ipsaro JJ, Mondragon A (2010) Structural basis for spectrin recognition by ankyrin. Blood 115:4093-4101

24. Korsgren C, Peters LL, Lux SE (2010) Protein 4.2 binds to the carboxyl-terminal EF-hands of erythroid alpha-spectrin in a calcium- and calmodulin-dependent manner. J Biol Chem 285:4757-4770

25. Ipsaro JJ, Huang L, Mondragon A (2009) Structures of the spectrin-ankyrin interaction binding domains. Blood 113:5385-5393

26. Low PS (2009) Where spectrin snuggles with ankyrin. Blood 113:5372-5373

27. Van Kim CL, Colin Y, Cartron JP (2006) Rh proteins: key structural and functional components of the red cell membrane. Blood Rev 20:93-110

28. Diakowski W, Ozimek L, Bielska E, Bem S, Langner M et al (2006) Cholesterol affects spectrin-phospholipid interactions in a manner different from changes resulting from alterations in membrane fluidity due to fatty acyl chain composition. Biochim Biophys Acta 1758:4-12

29. Sikorski AF, Sangerman J, Goodman SR, Critz SD (2000) Spectrin (betaSpIIsigma1) is an essential component of synaptic transmission. Brain Res 852:161-166

30. Thompson JM, Ellis RE, Green EM, Winlove CP, Petrov PG (2008) Spectrin maintains the lateral order in phosphatidylserine monolayers. Chem Phys Lipids 151:66-68

31. Grzybek M, Chorzalska A, Bok E, Hryniewicz-Jankowska A, Czogalla A et al (2006) Spectrin-phospholipid interactions. Existence of multiple kinds of binding sites? Chem Phys Lipids 141:133-141

32. Chorzalska A, Lach A, Borowik T, Wolny M, HryniewiczJankowska A et al (2010) The effect of the lipid-binding site of the ankyrin-binding domain of erythroid beta-spectrin on the properties of natural membranes and skeletal structures. Cell Mol Biol Lett 15:406-423

33. Wolny M, Grzybek M, Bok E, Chorzalska A, Lenoir M et al (2011) Key amino acid residues of ankyrin-sensitive phosphatidylethanolamine/phosphatidylcholine-lipid binding site of betal-spectrin. PLoS One 6:e21538

34. An X, Guo X, Gratzer W, Mohandas N (2005) Phospholipid binding by proteins of the spectrin family: a comparative study. Biochem Biophys Res Commun 327:794-800

35. Collec E, Lecomte MC, El-Nemer W, Colin Y, Le Van Kim C (2011) Novel role for the Lu/BCAM-spectrin interaction in actin cytoskeleton reorganization. Biochem $\mathrm{J}$

36. Gauthier E, El Nemer W, Wautier MP, Renaud O, Tchernia G et al (2010) Role of the interaction between Lu/BCAM and the spectrin-based membrane skeleton in the increased adhesion of hereditary spherocytosis red cells to laminin. Br J Haematol 148:456-465

37. Dhermy D, Schrevel J, Lecomte MC (2007) Spectrin-based skeleton in red blood cells and malaria. Curr Opin Hematol 14:198-202

38. Musacchio A, Noble M, Pauptit R, Wierenga R, Saraste M (1992) Crystal structure of a Src-homology 3 (SH3) domain. Nature 359:851-855

39. Lundberg S, Buevich AV, Sethson I, Edlund U, Backman L (1997) Calcium-binding mechanism of human nonerythroid alpha-spectrin EF-structures. Biochemistry 36:7199-7208

40. Trave G, Lacombe PJ, Pfuhl M, Saraste M, Pastore A (1995) Molecular mechanism of the calcium-induced conformational change in the spectrin EF-hands. Embo J 14:4922-4931

41. Trave G, Pastore A, Hyvonen M, Saraste M (1995) The C-terminal domain of alpha-spectrin is structurally related to calmodulin. Eur J Biochem 227:35-42 
42. Okabe T, Sobue K (1987) Identification of a new $84 / 82 \mathrm{kDa}$ calmodulin-binding protein, which also interacts with actin filaments, tubulin and spectrin, as synapsin I. FEBS Lett 213:184-188

43. Rotter B, Kroviarski Y, Nicolas G, Dhermy D, Lecomte MC (2004) AlphaII-spectrin is an in vitro target for caspase-2, and its cleavage is regulated by calmodulin binding. Biochem $\mathrm{J}$ 378:161-168

44. Nicolas G, Fournier CM, Galand C, Malbert-Colas L, Bournier O et al (2002) Tyrosine phosphorylation regulates alpha II spectrin cleavage by calpain. Mol Cell Biol 22:3527-3536

45. Banuelos S, Saraste M, Djinovic Carugo K (1998) Structural comparisons of calponin homology domains: implications for actin binding. Structure 6:1419-1431

46. Karinch AM, Zimmer WE, Goodman SR (1990) The identification and sequence of the actin-binding domain of human red blood cell beta-spectrin. J Biol Chem 265:11833-11840

47. Musacchio A, Gibson T, Rice P, Thompson J, Saraste M (1993) The PH domain: a common piece in the structural patchwork of signalling proteins. Trends Biochem Sci 18:343-348

48. Saraste M, Hyvonen M (1995) Pleckstrin homology domains: a fact file. Curr Opin Struct Biol 5:403-408

49. Stankewich MC, Tse WT, Peters LL, Ch'ng Y, John KM et al (1998) A widely expressed betaIII spectrin associated with Golgi and cytoplasmic vesicles. Proc Natl Acad Sci USA 95:14158-14163

50. Bennett V, Baines AJ (2001) Spectrin and ankyrin-based pathways: metazoan inventions for integrating cells into tissues. Physiol Rev 81:1353-1392

51. Delaunay J (2007) The molecular basis of hereditary red cell membrane disorders. Blood Rev 21:1-20

52. Perrotta S, Gallagher PG, Mohandas N (2008) Hereditary spherocytosis. Lancet 372:1411-1426

53. Bennett V, Healy J (2008) Organizing the fluid membrane bilayer: diseases linked to spectrin and ankyrin. Trends Mol Med 14:28-36

54. Goodman SR, Zagon IS, Kulikowski RR (1981) Identification of a spectrin-like protein in nonerythroid cells. Proc Natl Acad Sci USA 78:7570-7574

55. Wu S, Sangerman J, Li M, Brough GH, Goodman SR et al (2001) Essential control of an endothelial cell ISOC by the spectrin membrane skeleton. J Cell Biol 154:1225-1233

56. Kizhatil K, Davis JQ, Davis L, Hoffman J, Hogan BL et al (2007) Ankyrin-G is a molecular partner of E-cadherin in epithelial cells and early embryos. J Biol Chem 282:26552-26561

57. Kizhatil K, Yoon W, Mohler PJ, Davis LH, Hoffman JA et al (2007) Ankyrin-G and beta2-spectrin collaborate in biogenesis of lateral membrane of human bronchial epithelial cells. J Biol Chem 282:2029-2037

58. Lee HG, Zarnescu DC, MacIver B, Thomas GH (2010) The cell adhesion molecule Roughest depends on beta(Heavy)-spectrin during eye morphogenesis in Drosophila. J Cell Sci 123:277-285

59. Stabach PR, Morrow JS (2000) Identification and characterization of beta V spectrin, a mammalian ortholog of Drosophila beta $\mathrm{H}$ spectrin. J Biol Chem 275:21385-21395

60. Legendre K, Safieddine S, Kussel-Andermann P, Petit C, El-Amraoui A (2008) alphaII-betaV spectrin bridges the plasma membrane and cortical lattice in the lateral wall of the auditory outer hair cells. J Cell Sci 121:3347-3356

61. Leshchyns'ka I, Tanaka M, Schachner M, Sytnyk V (2011) Immobilized pool of NCAM180 in the postsynaptic membrane is homeostatically replenished by the flux of NCAM180 from extrasynaptic regions. J Biol Chem

62. Leshchyns'ka I, Sytnyk V, Morrow JS, Schachner M (2003) Neural cell adhesion molecule (NCAM) association with
PKCbeta2 via betaI spectrin is implicated in NCAM-mediated neurite outgrowth. J Cell Biol 161:625-639

63. Atz ME, Rollins B, Vawter MP (2007) NCAM1 association study of bipolar disorder and schizophrenia: polymorphisms and alternatively spliced isoforms lead to similarities and differences. Psychiatr Genet 17:55-67

64. Ramser EM, Buck F, Schachner M, Tilling T (2010) Binding of alphaII spectrin to 14-3-3beta is involved in NCAM-dependent neurite outgrowth. Mol Cell Neurosci 45:66-74

65. Djinovic-Carugo K, Gautel M, Ylanne J, Young P (2002) The spectrin repeat: a structural platform for cytoskeletal protein assemblies. FEBS Lett 513:119-123

66. Odell AF, Van Helden DF, Scott JL (2008) The spectrin cytoskeleton influences the surface expression and activation of human transient receptor potential channel 4 channels. J Biol Chem 283:4395-4407

67. Ikeda Y, Dick KA, Weatherspoon MR, Gincel D, Armbrust KR et al (2006) Spectrin mutations cause spinocerebellar ataxia type 5. Nat Genet 38:184-190

68. Lorenzo DN, Li MG, Mische SE, Armbrust KR, Ranum LP et al (2010) Spectrin mutations that cause spinocerebellar ataxia type 5 impair axonal transport and induce neurodegeneration in Drosophila. J Cell Biol 189:143-158

69. Stankewich MC, Gwynn B, Ardito T, Ji L, Kim J et al (2010) Targeted deletion of betaIII spectrin impairs synaptogenesis and generates ataxic and seizure phenotypes. Proc Natl Acad Sci USA 107:6022-6027

70. Jackson M, Song W, Liu MY, Jin L, Dykes-Hoberg M et al (2001) Modulation of the neuronal glutamate transporter EAAT4 by two interacting proteins. Nature 410:89-93

71. Perkins EM, Clarkson YL, Sabatier N, Longhurst DM, Millward CP et al (2010) Loss of beta-III spectrin leads to Purkinje cell dysfunction recapitulating the behavior and neuropathology of spinocerebellar ataxia type 5 in humans. $J$ Neurosci 30:4857-4867

72. Parkinson NJ, Olsson CL, Hallows JL, McKee-Johnson J, Keogh BP et al (2001) Mutant beta-spectrin 4 causes auditory and motor neuropathies in quivering mice. Nat Genet 29:61-65

73. Komada M, Soriano P (2002) [Beta]IV-spectrin regulates sodium channel clustering through ankyrin-G at axon initial segments and nodes of Ranvier. J Cell Biol 156:337-348

74. Dubreuil RR, Wang P, Dahl S, Lee J, Goldstein LS (2000) Drosophila beta spectrin functions independently of alpha spectrin to polarize the $\mathrm{Na}, \mathrm{K}$ ATPase in epithelial cells. J Cell Biol 149:647-656

75. Tang Y, Katuri V, Dillner A, Mishra B, Deng CX et al (2003) Disruption of transforming growth factor-beta signaling in ELF beta-spectrin-deficient mice. Science 299:574-577

76. Conrotto P, Yakymovych I, Yakymovych M, Souchelnytskyi S (2007) Interactome of transforming growth factor-beta type I receptor (TbetaRI): inhibition of TGFbeta signaling by Epac1. J Proteome Res 6:287-297

77. Nebl T, Pestonjamasp KN, Leszyk JD, Crowley JL, Oh SW et al (2002) Proteomic analysis of a detergent-resistant membrane skeleton from neutrophil plasma membranes. J Biol Chem 277:43399-43409

78. Becamel C, Gavarini S, Chanrion B, Alonso G, Galeotti N et al (2004) The serotonin 5-HT2A and 5-HT2C receptors interact with specific sets of PDZ proteins. J Biol Chem 279:20257-20266

79. Husi H, Ward MA, Choudhary JS, Blackstock WP, Grant SG (2000) Proteomic analysis of NMDA receptor-adhesion protein signaling complexes. Nat Neurosci 3:661-669

80. Baek HJ, Kim SS, da Silva FM, Volpe EA, Evans S et al (2006) Inactivation of TGF-beta signaling in lung cancer results in increased CDK4 activity that can be rescued by ELF. Biochem Biophys Res Commun 346:1150-1157 
81. Kim SS, Shetty K, Katuri V, Kitisin K, Baek HJ et al (2006) TGF-beta signaling pathway inactivation and cell cycle deregulation in the development of gastric cancer: role of the betaspectrin, ELF. Biochem Biophys Res Commun 344:1216-1223

82. Kitisin K, Saha T, Blake T, Golestaneh N, Deng M, et al (2007) Tgf-Beta signaling in development. Sci STKE 2007: $\mathrm{cm} 1$

83. Yao ZX, Jogunoori W, Choufani S, Rashid A, Blake T et al (2010) Epigenetic silencing of beta-spectrin, a TGF-beta signaling/scaffolding protein in a human cancer stem cell disorder: Beckwith-Wiedemann syndrome. J Biol Chem 285:3611236120

84. Metral S, Machnicka B, Bigot S, Colin Y, Dhermy D et al (2009) AlphaII-spectrin is critical for cell adhesion and cell cycle. J Biol Chem 284:2409-2418

85. McMahon LW, Sangerman J, Goodman SR, Kumaresan K, Lambert MW (2001) Human alpha spectrin II and the FANCA, FANCC, and FANCG proteins bind to DNA containing psoralen interstrand cross-links. Biochemistry 40:7025-7034

86. Sridharan D, Brown M, Lambert WC, McMahon LW, Lambert MW (2003) Nonerythroid alphaII spectrin is required for recruitment of FANCA and XPF to nuclear foci induced by DNA interstrand cross-links. J Cell Sci 116:823-835

87. Sridharan DM, McMahon LW, Lambert MW (2006) alphaIISpectrin interacts with five groups of functionally important proteins in the nucleus. Cell Biol Int 30:866-878

88. Lefferts JA, Wang C, Sridharan D, Baralt M, Lambert MW (2009) The SH3 domain of alphaII spectrin is a target for the Fanconi anemia protein, FANCG. Biochemistry 48:254-263

89. Wang C, Lambert MW (2010) The Fanconi anemia protein, FANCG, binds to the ERCC1-XPF endonuclease via its tetratricopeptide repeats and the central domain of ERCC1. Biochemistry 49:5560-5569

90. McMahon LW, Zhang P, Sridharan DM, Lefferts JA, Lambert MW (2009) Knockdown of alphaII spectrin in normal human cells by siRNA leads to chromosomal instability and decreased DNA interstrand cross-link repair. Biochem Biophys Res Commun 381:288-293

91. Bialkowska K, Saido TC, Fox JE (2005) SH3 domain of spectrin participates in the activation of Rac in specialized calpaininduced integrin signaling complexes. J Cell Sci 118:381-395

92. Benz PM, Blume C, Moebius J, Oschatz C, Schuh K et al (2008) Cytoskeleton assembly at endothelial cell-cell contacts is regulated by alphaII-spectrin-VASP complexes. J Cell Biol 180:205-219

93. Rotter B, Bournier O, Nicolas G, Dhermy D, Lecomte MC (2005) AlphaII-spectrin interacts with Tes and EVL, two actinbinding proteins located at cell contacts. Biochem $\mathrm{J}$ 388:631-638

94. Bournier O, Kroviarski Y, Rotter B, Nicolas G, Lecomte MC et al (2006) Spectrin interacts with EVL (Enabled/vasodilatorstimulated phosphoprotein-like protein), a protein involved in actin polymerization. Biol Cell 98:279-293

95. Ziemnicka-Kotula D, Xu J, Gu H, Potempska A, Kim KS et al (1998) Identification of a candidate human spectrin Src homology 3 domain-binding protein suggests a general mechanism of association of tyrosine kinases with the spectrin-based membrane skeleton. J Biol Chem 273:13681-13692

96. Dubielecka PM, Ladwein KI, Xiong X, Migeotte I, Chorzalska A et al (2011) Essential role for Abil in embryonic survival and WAVE2 complex integrity. Proc Natl Acad Sci USA 108:7022-7027

97. Derry JM, Ochs HD, Francke U (1994) Isolation of a novel gene mutated in Wiskott-Aldrich syndrome. Cell 79:following 922

98. Nonoyama S, Ochs HD (1998) Characterization of the WiskottAldrich syndrome protein and its role in the disease. Curr Opin Immunol 10:407-412
99. Iida N, Lokeshwar VB, Bourguignon LY (1994) Mapping the fodrin binding domain in CD45, a leukocyte membrane-associated tyrosine phosphatase. J Biol Chem 269:28576-28583

100. Pradhan D, Morrow J (2002) The spectrin-ankyrin skeleton controls CD45 surface display and interleukin-2 production. Immunity 17:303-315

101. Kung C, Pingel JT, Heikinheimo M, Klemola T, Varkila K et al (2000) Mutations in the tyrosine phosphatase CD45 gene in a child with severe combined immunodeficiency disease. Nat Med 6:343-345

102. Tchilian EZ, Beverley PC (2006) Altered CD45 expression and disease. Trends Immunol 27:146-153

103. Tchilian EZ, Wallace DL, Wells RS, Flower DR, Morgan G et al (2001) A deletion in the gene encoding the CD45 antigen in a patient with SCID. J Immunol 166:1308-1313

104. Wallace VA, Penninger JM, Kishihara K, Timms E, Shahinian A et al (1997) Alterations in the level of CD45 surface expression affect the outcome of thymic selection. J Immunol 158:3205-3214

105. Repasky EA, Pollina CM, Menold MM, Hudecki MS (1986) Increased concentration of spectrin is observed in avian dystrophic muscle. Proc Natl Acad Sci USA 83:802-806

106. Ghaffari-Tabrizi N, Bauer B, Villunger A, Baier-Bitterlich G, Altman A et al (1999) Protein kinase Ctheta, a selective upstream regulator of JNK/SAPK and IL-2 promoter activation in Jurkat T cells. Eur J Immunol 29:132-142

107. Trushin SA, Pennington KN, Algeciras-Schimnich A, Paya CV (1999) Protein kinase C and calcineurin synergize to activate IkappaB kinase and NF-kappaB in T lymphocytes. J Biol Chem 274:22923-22931

108. Masso-Welch PA, Black JD, Erikson J, Repasky EA (1999) Polarized expression of immunoglobulin, spectrin, and protein kinase $\mathrm{C}$ beta II occurs in B cells from normal BALB/c, autoimmune lpr, and anti-ssDNA transgenic, tolerant mice. J Leukoc Biol 66:617-624

109. Kwiatkowska K, Sobota A (1999) Engagement of spectrin and actin in capping of FcgammaRII revealed by studies on permeabilized U937 cells. Biochem Biophys Res Commun 259:287-293

110. Dubielecka PM, Grzybek M, Kolondra A, Jazwiec B, Draga A et al (2010) Aggregation of spectrin and PKCtheta is an early hallmark of fludarabine/mitoxantrone/dexamethasone-induced apoptosis in Jurkat T and HL60 cells. Mol Cell Biochem 339:63-77

111. Dubielecka PM, Jazwiec B, Potoczek S, Wrobel T, Miloszewska $\mathrm{J}$ et al (2005) Changes in spectrin organisation in leukaemic and lymphoid cells upon chemotherapy. Biochem Pharmacol 69:73-85

112. Devarajan P, Stabach PR, De Matteis MA, Morrow JS (1997) $\mathrm{Na}, \mathrm{K}-\mathrm{ATPase}$ transport from endoplasmic reticulum to Golgi requires the Golgi spectrin-ankyrin G119 skeleton in Madin Darby canine kidney cells. Proc Natl Acad Sci USA 94:10711-10716

113. Holleran EA, Ligon LA, Tokito M, Stankewich MC, Morrow JS et al (2001) beta III spectrin binds to the Arp1 subunit of dynactin. J Biol Chem 276:36598-36605

114. Clarkson YL, Gillespie T, Perkins EM, Lyndon AR, Jackson M (2010) Beta-III spectrin mutation L253P associated with spinocerebellar ataxia type 5 interferes with binding to Arp1 and protein trafficking from the Golgi. Hum Mol Genet 19:3634-3641

115. Czogalla A, Sikorski AF (2005) Spectrin and calpain: a 'target' and a 'sniper' in the pathology of neuronal cells. Cell Mol Life Sci 62:1913-1924

116. Lee A, Morrow JS, Fowler VM (2001) Caspase remodeling of the spectrin membrane skeleton during lens development and aging. J Biol Chem 276:20735-20742 
117. Wang KK, Posmantur R, Nath R, McGinnis K, Whitton M et al (1998) Simultaneous degradation of alphaII- and betaII-spectrin by caspase 3 (CPP32) in apoptotic cells. J Biol Chem 273:22490-22497

118. Glantz SB, Cianci CD, Iyer R, Pradhan D, Wang KK et al (2007) Sequential degradation of alphaII and betaII spectrin by calpain in glutamate or maitotoxin-stimulated cells. Biochemistry 46:502-513

119. Gauster M, Siwetz M, Orendi K, Moser G, Desoye G et al (2010) Caspases rather than calpains mediate remodelling of the fodrin skeleton during human placental trophoblast fusion. Cell Death Differ 17:336-345

120. Manno S, Takakuwa Y, Nagao K, Mohandas N (1995) Modulation of erythrocyte membrane mechanical function by betaspectrin phosphorylation and dephosphorylation. J Biol Chem 270:5659-5665

121. Perrotta S, del Giudice EM, Iolascon A, De Vivo M, Di Pinto D et al (2001) Reversible erythrocyte skeleton destabilization is modulated by beta-spectrin phosphorylation in childhood leukemia. Leukemia 15:440-444

122. Pinder JC, Bray D, Gratzer WB (1977) Control of interaction of spectrin and actin by phosphorylation. Nature 270:752-754

123. Fowler VM, Adam EJ (1992) Spectrin redistributes to the cytosol and is phosphorylated during mitosis in cultured cells. J Cell Biol 119:1559-1572

124. Siddhanta A, Radulescu A, Stankewich MC, Morrow JS, Shields D (2003) Fragmentation of the Golgi apparatus. A role for beta III spectrin and synthesis of phosphatidylinositol 4, 5-bisphosphate. J Biol Chem 278:1957-1965

125. Nedrelow JH, Cianci CD, Morrow JS (2003) c-Src binds alpha II spectrin's Src homology 3 (SH3) domain and blocks calpain susceptibility by phosphorylating Tyr1176. J Biol Chem 278:7735-7741
126. Kamal A, Ying Y, Anderson RG (1998) Annexin VI-mediated loss of spectrin during coated pit budding is coupled to delivery of LDL to lysosomes. J Cell Biol 142:937-947

127. Meary F, Metral S, Ferreira C, Eladari D, Colin Y et al (2007) A mutant alphaII-spectrin designed to resist calpain and caspase cleavage questions the functional importance of this process in vivo. J Biol Chem 282:14226-14237

128. Hund TJ, Koval OM, Li J, Wright PJ, Qian L et al (2010) A beta(IV)-spectrin/CaMKII signaling complex is essential for membrane excitability in mice. J Clin Invest 120:3508-3519

129. Saitsu H, Tohyama J, Kumada T, Egawa K, Hamada K et al (2010) Dominant-negative mutations in alpha-II spectrin cause West syndrome with severe cerebral hypomyelination, spastic quadriplegia, and developmental delay. Am J Hum Genet $86: 881-891$

130. Tse WT, Tang J, Jin O, Korsgren C, John KM et al (2001) A new spectrin, beta IV, has a major truncated isoform that associates with promyelocytic leukemia protein nuclear bodies and the nuclear matrix. J Biol Chem 276:23974-23985

131. Krieger CC, An X, Tang HY, Mohandas N, Speicher DW et al (2011) Cysteine shotgun-mass spectrometry (CS-MS) reveals dynamic sequence of protein structure changes within mutant and stressed cells. Proc Natl Acad Sci USA 108: 8269-8274

132. Zhang Y, Resneck WG, Lee PC, Randall WR, Bloch RJ, et al (2010) Characterization and expression of a heart-selective alternatively spliced variant of alpha II-spectrin, cardi+, during development in the rat. J Mol Cell Cardiol 48:1050-1059

133. Susuki K, Rasband MN (2008) Molecular mechanisms of node of Ranvier formation. Curr Opin Cell Biol 20:616-623

134. Martin PM, Cifuentes-Diaz C, Garcia M, Goutebroze L, Girault JA (2008) [Axon and Schwann cells... so far away, so close]. Rev Neurol (Paris) 164:1057-1062 